\title{
Abnormalities of Urinary Tract and Skeleton Associated with Congenital Absence of Vagina
}

\author{
S. CHAWLA,* M.B., B.S., D.M.R. ; K. BERY,* M.B., B.S., D.M.R.D. ; K. J. INDRA,* M.B., B.S., D.M.R.D.
}

Brit. med. F., 1966, 1, 1398-1400

Congenital absence of the vagina was first mentioned by Realdus Columbus in 1572 (quoted by Bryan, Nigro, and Counseller, 1949). The incidence has been variously reported as 1 in 4,000 female patients (Bryan et al., 1949), 1 in 5,000 births (Engstad, 1917), and 6 in 125,000 female hospital admissions (Owens, 1942). The largest series was reported by Phelan, Counseller, and Greene (1953), who saw 129 patients with absence of the vagina at the Mayo Clinic. Excretory urography was done on only 72 , and $26(36 \%)$ of these were found to have abnormalities of the urinary tract. A similar incidence was reported in a smaller series studied at the Johns Hopkins Hospital, where four cases out of 11 showed abnormalities of the urinary tract (Novak and Jones, 1961). Of 41 cases of this condition studied by Bryan et al. (1949) 21 showed abnormalities of the urinary

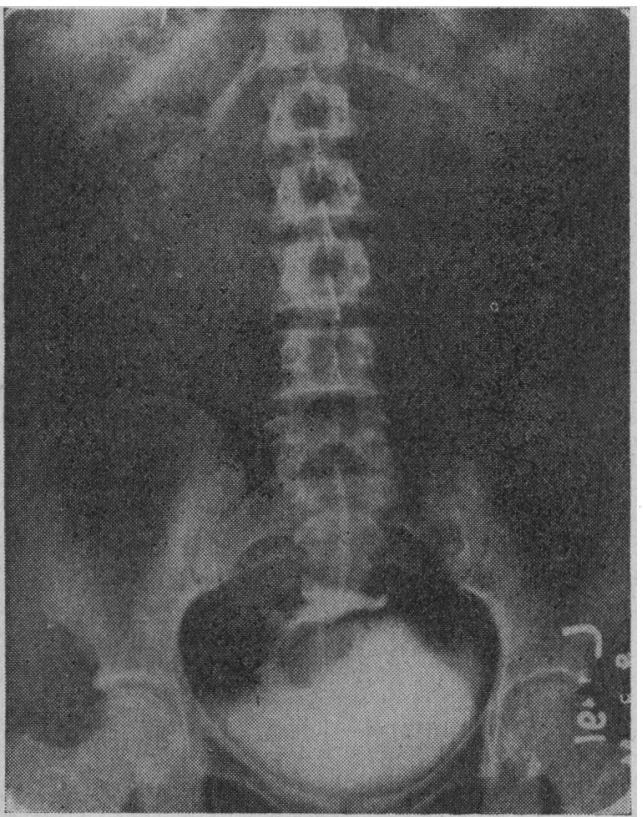

FIG. 1

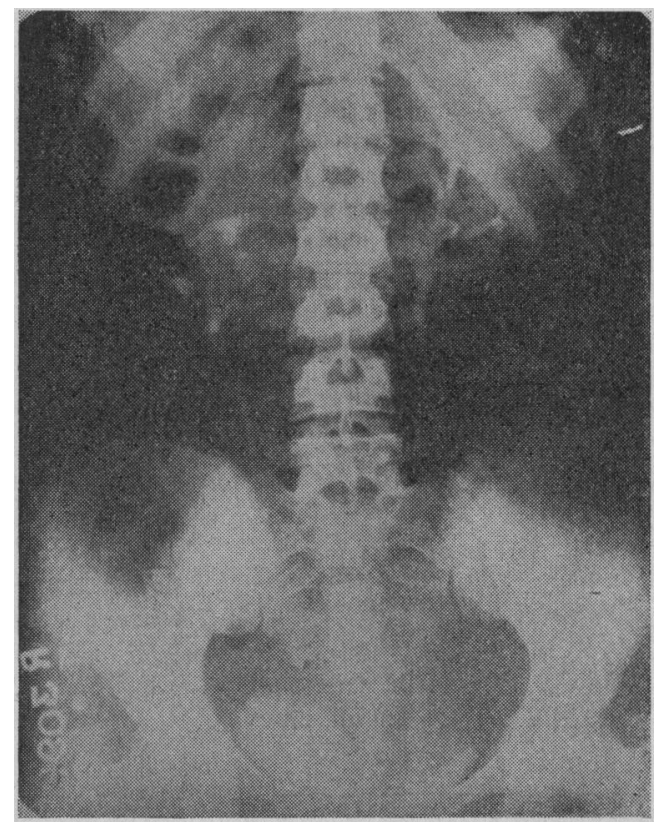

FIG. 2
Fig. 1.-Case 12. Intravenous pyelography showing absence of the renal outlines in their normal anatomical position. Solitary pelvic kidney with malformed calices and pelvis and a single short ureter opening into the bladder. FIG. 2 . -Case 4. Intravenous pyelography showing malrotated right kidney with its calices directed medially and the ureter arising from its lateral border.

\begin{tabular}{|c|c|c|c|c|c|c|c|c|}
\hline \multirow{2}{*}{$\begin{array}{l}\text { Case } \\
\text { No. }\end{array}$} & \multirow{2}{*}{$\begin{array}{l}\text { Age } \\
\text { in } \\
\text { Years }\end{array}$} & \multirow{2}{*}{$\begin{array}{l}\text { Presenting } \\
\text { Symptoms }\end{array}$} & \multicolumn{3}{|c|}{ Clinical Signs } & \multicolumn{2}{|c|}{ Finding on I.V.P. } & \multirow{2}{*}{$\begin{array}{c}\text { Finding on } \\
X \text {-ray } \\
\text { Film of Skeleton }\end{array}$} \\
\hline & & & Vagina & Cervix & Uterus & L. Kidney & R. Kidney & \\
\hline $\begin{array}{l}1 \\
2 \\
3 \\
4 \\
5\end{array}$ & $\begin{array}{l}35 \\
16 \\
17 \\
16 \\
20\end{array}$ & $\begin{array}{l}\text { P.S. P.A. } \\
\text { P.A. } \\
\text { P.A. } \\
\text { P.A. } \\
\text { P.A. }\end{array}$ & $\begin{array}{l}\text { Absent } \\
\text { "”, ' } \\
\text { Atresia; haematocolpos } \\
\text { Atresia }\end{array}$ & & $\begin{array}{c}\text { Absent } \\
, " \\
",\end{array}$ & \multicolumn{2}{|c|}{$\mid \begin{array}{l}\text { Ectopic on L. } \\
\text { Malrotated }\end{array}$} & \multirow{2}{*}{$\begin{array}{l}\text { Hemi-vertebrae and spina bifida } \\
\text { of the cervical spine, lumbar- } \\
\text { ization of } S 1\end{array}$} \\
\hline $\begin{array}{r}6 \\
7 \\
8 \\
9 \\
10 \\
11\end{array}$ & $\begin{array}{l}22 \\
16 \\
17 \\
32 \\
21 \\
19\end{array}$ & $\begin{array}{l}\text { P.A. } \\
\text { P.A. } \\
\text { P.A. } \\
\text { P.A. P.S. } \\
\text { P.A. } \\
\text { P.A. }\end{array}$ & $\begin{array}{l}\text { Shallow } \\
\text { Absent } \\
\text { Shallow } \\
\text { Absent }\end{array}$ & $\begin{array}{l}\text { Absent } \\
\text { Rudimentary } \\
\text { Absent }\end{array}$ & $\begin{array}{l}\text { Absent } \\
\text {," } \\
\text { Rudimentary } \\
\text { Absent } \\
\text {," }\end{array}$ & \multicolumn{2}{|c|}{\begin{tabular}{c|c} 
Ectopic \\
Solitary pelvic kidney
\end{tabular}} & \\
\hline+12 & 18 & P.A. P.S. & Atresia & & & " & & \multirow{3}{*}{ 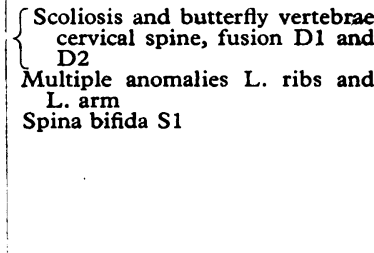 } \\
\hline 13 & 21 & P.A. Abd.P. & Shallow & & $"$ & Absent & & \\
\hline $\begin{array}{r}14 \\
15 \\
16 \\
17 \\
18 \\
+19\end{array}$ & $\begin{array}{l}19 \\
19 \\
20 \\
18 \\
17 \\
22\end{array}$ & $\begin{array}{l}\text { P.A. } \\
\text { P.A. } \\
\text { P.A. } \\
\text { P.A. Abd.P. } \\
\text { P.A. Abd.P. } \\
\text { P.A. P.S. Abd.P. }\end{array}$ & $\begin{array}{l}\text { Absent } \\
\text { Shallow } \\
\text { Absent } \\
\text { Shallow } \\
\text { Absent } \\
\text { Shallow }\end{array}$ & " & $\begin{array}{l}\text { "' } \\
\text { "' } \\
\text { ", } \\
\text { "' }\end{array}$ & \multicolumn{2}{|c|}{ Solitary pelvic kidney } & \\
\hline $\begin{array}{l}20 \\
21 \\
22 \\
23\end{array}$ & $\begin{array}{l}25 \\
18 \\
20 \\
19\end{array}$ & $\begin{array}{l}\text { P.A. D. } \\
\text { P.A. Abd.P. } \\
\text { P.A. D. } \\
\text { P.A. Abd.P. }\end{array}$ & ", & ", & $\begin{array}{l}\text { "' } \\
\text { "' }\end{array}$ & $\begin{array}{l}\text { Ectopic in } \\
\text { pelvis }\end{array}$ & Absent & \\
\hline
\end{tabular}

† Cases already reported in Indian F. Radiol., 1964, 18.

P.S. $=$ Primary sterility. P.A. $=$ Primary amenorrhoea.$\quad$ Abd.P. $=$ Abdominal pain. D. $=$ Dyspareunia.

* Radiology Department, Lady Hardinge Medical College and Hospital, New Delhi 
tract of various types, an incidence of $51 \%$. Chawla, Gadekar, Nirula, and Hingorani (1963) reported 18 cases of congenital abnormalities of the genital tract from another institute. Their series included 10 cases of congenital absence of the vagina, and seven of them showed abnormalities of the urinary tract. In the present series, of the 23 cases studied 11 showed various abnormalities of the urinary tract.

\section{Material and Methods}

Twenty-three patients with congenital absence of the vagina were investigated in the Radiology Department of the Lady Hardinge Medical College Hospital. Intravenous pyelography was done in all the cases to study the anatomy of the urinary tract, and cystoscopy was done in some cases to confirm the

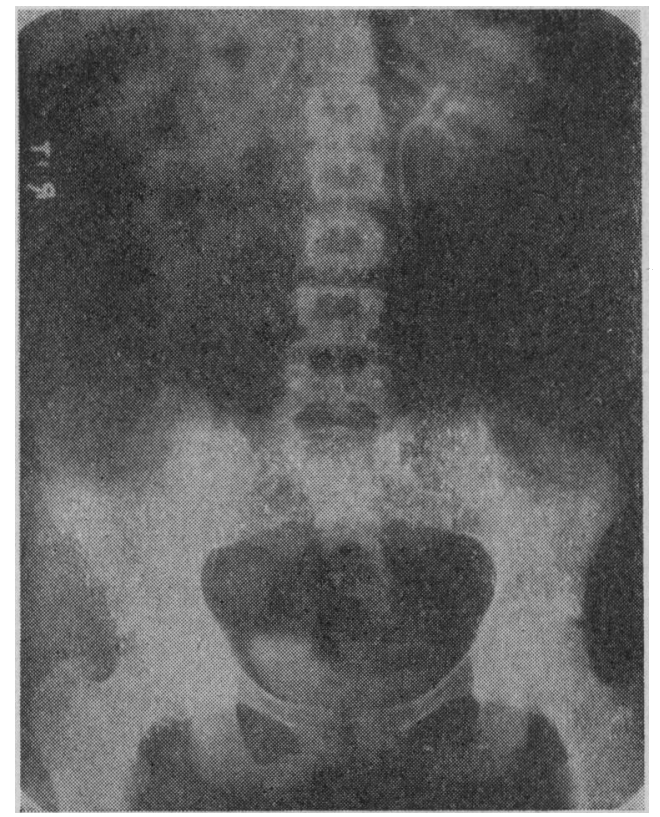

FIG. 3

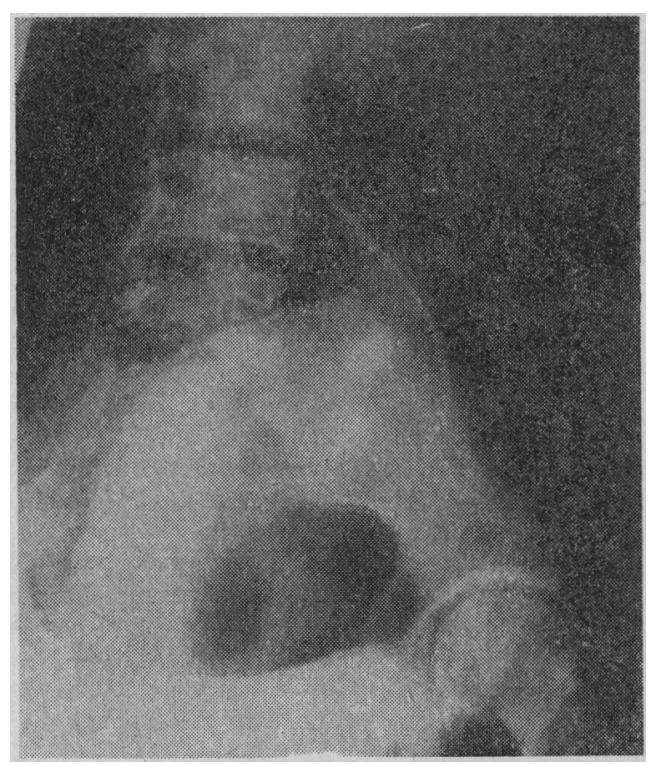

FIG. 4

Figs. 3 and 4.-Case 2. Intravenous pyelography showing left kidney normal in size, shape, position, and obliquity. Left ureter displaced laterally at the level of the transverse process of the lumbar fourth and fifth vertebrae and the first piece of the sacrum by the ectopic right kidney showing mafformed by the ectopic right kidney showing malformed
calices. The calices of the ectopic right kidney and the displacement of the ureter of the normal side is seen better on the oblique view of the pelvis. diagnosis. Radiological investigation for skeletal abnormalities was carried out when clinical examination suggested any abnormality, but a routine skeletal survey was not undertaken in all the cases.

\section{Results}

The age of the patients in our series varied from 16 to 35 years, with an average of 20 . All the patients suffered from primary amenorrhoea, though abdominal pain, primary sterility, and inability to have intercourse were the presenting conditions in some.

The results of the radiological investigations are shown in the Table.

Of the 23 patients investigated 11 showed urological abnormalities, an incilence of $48 \%$. Ten had significant lesions, while one had only malrotation of one of the kidneys. None of the patients complained of symptoms referable to the urinary tract, though Case 19 had a solitary pelvic kidney with multiple calculi. Examination of this patient's urine revealed pyuria, and Escherichia coli was isolated on urine culture. Five patients were found to have a solitary pelvic kidney, and in four of these a suprapubic mass was palpable. A further five

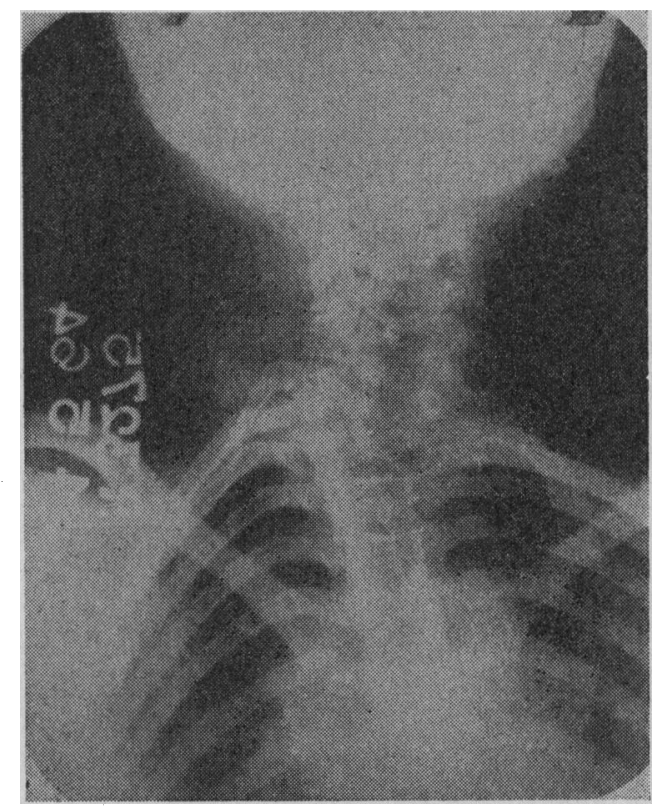

Fig. 5.-Case 5. Antero-posterior view of the cervical spine showing spina bifida and multiple hemivertebrae causing scoliosis.

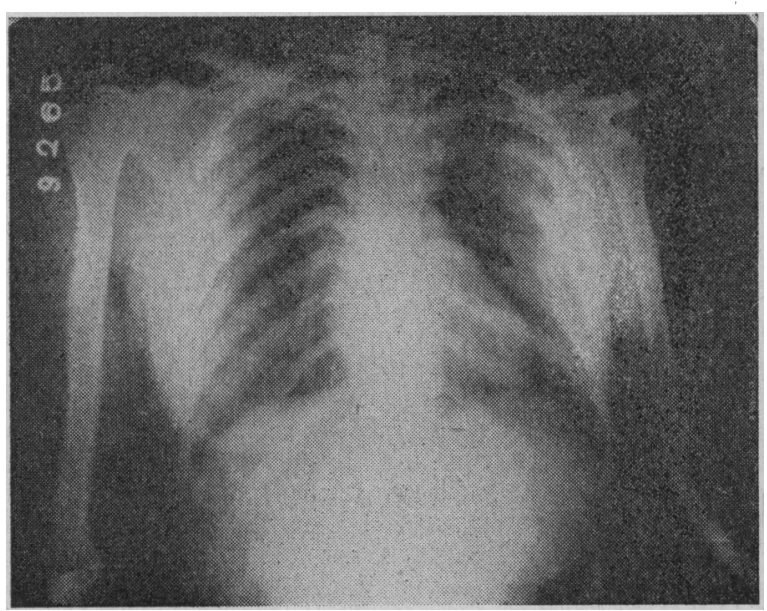

Fig. 6-Case 13. $X$-ray film of chest and upper arm showing congenital fusion of left first to eighth ribs. Scapula is small; the head of the humerus, the radius, and the radial sector of the hand are absent on the left side. 
patients were found to have solitary kidneys-two situated normally and three in various ectopic sites. The appearances of the intravenous pyelograms in three of these cases are shown in Figs. 1 to 4 .

Skeletal abnormalities were found in four patients, three of whom had solitary kidneys. $X$-ray films of two of these cases are shown in Figs. 5 and 6 . Cases 5 and 12 had webbing of the neck on clinical examination. Case 5 had hemivertebrae and spina bifida of the cervical spine and lumbarization of the first sacral segment. Case 12 showed scoliosis of the cervicodorsal spine with a butterfly vertebra at C.7 and congenital fusion of the first and second dorsal vertebrae. Case 13 showed congenital fusion of the left first to eighth ribs and a small scapula. The head of the left humerus, the left radius, and the left radial sector of the hand were absent.

\section{Discussion}

The various skeletal abnormalities associated with absence of the vagina have been given insufficient attention. Of the 11 cases reported from the Johns Hopkins Hospital (Novak and Jones, 1961) only one case was reported as showing a skeletal abnormality, lumbarization of the sacral segment. Bryan et al. (1949) reported six cases showing various skeletal abnormalities among the 100 cases of absence of vagina. These anomalies of the skeleton included congenital dislocation of the hip ; malformations of the foot, arms, and ribs ; cervical spina bifida ; hemivertebrae in the lumbar spine; rudimentary first rib; and sacralization of the fifth lumbar vertebra. A much higher incidence of abnormalities of the skeleton was reported by Chawla et al. (1963). In their series of 18 cases of congenital lesions of the genital tract four showed skeletal abnormality. In the present series four cases showed skeletal anomalies.
Since the incidence of malformations of the urinary tract associated with absence of the vagina is very high, a proper functional and anatomical evaluation of the urinary tract is mandatory before surgery is undertaken. The presence of an ectopic pelvic kidney may interfere with reconstructive surgery. A pelvic kidney and its ureter may be injured during the surgical procedure if its position is not known pre-operatively, as had been emphasized by Pommerenke and Benjamin (1947) and by Woolf and Allen (1953).

\section{Summary}

Twenty-three cases of congenital absence of the vagina are presented. Eleven of these presented various abnormalities of the upper urinary tract, 10 of which were significant. The importance of urinary tract studies is stressed.

Skeletal abnormalities were found in four patients, and it is suggested that insufficient attention has been paid to the incidence of bone abnormality in this condition.

We are grateful to the Editor of the Indian Fournal of Radiology for permission to reproduce Fig. 1.

\section{REFERENCES}

Bryan, A. L., Nigro, J. A., and Counseller, V. S. (1949). Surg. Gynec. Obstet., 88, 79.

Chawla, S., Gadekar, N. G., Nirula, R., and Hingorani, V. (1963). Indian 7. Surg., 25, 600 .

Engstad, J. E. (1917). Lancet, 37, 329.

Novak, E. R., and Jones, G. S. (1961). Textbook of Gynaecology, 6th ed., p. 124. Williams and Wilkins, Baltimore.

Owens, N. (1942). Surgery, 12, 139.

Phelan, J. T., Counseller, V. S., and Green, L. F. (1953). Surg. Gynec. Obstet., 97,1 .

Pommerenke, W. T., and Benjamin, J. A. (1947). N.Y. St. F. Med., 47,

Woolf, R. B., and Allen, W. M. (1953). Obstet. and Gynec., 2, 236.

\title{
Bronchopulmonary Geotrichosis with Severe Asthma
}

\author{
J. D. ROSS,* M.B., CH.B., F.R.C.P.ED., M.P.H.; K. D. G. REID, † M.B., CH.B., D.P.H. \\ C. F. SPEIRS, $\ddagger$ M.B., CH.B., M.R.C.P.ED.
}

Brit. med. F., 1966, 1, 1400-1402

Bronchopulmonary geotrichosis is a rare disease caused by the fungus Geotrichum candidum. It has been described most commonly in South America, but has also been reported in North America, Scandinavia, France, and Great Britain. In describing what is probably the third case in the British literature, we draw attention to the possible seriousness of the illness. The severe asthma in this case is a feature not previously reported. The problems of management are described.

\section{Case Report}

In January 1963 a 46-year-old non-smoking previously healthy Edinburgh housewife who had never been abroad developed a severe expiratory wheeze and a cough initially productive of white sputum. During the next two months her general health deteriorated. Because the sputum had become purulent and copious her general practitioner prescribed tetracycline. As she did not improve, she was admitted to hospital on 14 April.

- Consultant Chest Physician, City Hospital, Edinburgh.

† Chest Physician, City Hospital, Edinburgh.

₹ Lately Senior House Officer, Department of Respiratory Diseases and Tuberculosis, City Hospital, Edinburgh.

\section{First Admission}

On admission, although apyrexial, she was exceedingly ill and wasted. An almost incessant cough produced copious green foulsmelling sputum, and a loud expiratory wheeze was audible to the unaided ear. Chest expansion was poor, and rhonchi and coarse crepitations were heard throughout both lung fields. There was probably early finger-clubbing. Haematological findings were: $\mathrm{Hb} 87 \%$; E.S.R. $30 \mathrm{~mm}$. in first hour (Westergren); W.B.C. $10,100 /$ c.mm. ( $10 \%$ eosinophils). Eosinophils were also present in the sputum. Sputum specimens were cultured aerobically and anaerobically on blood agar but no pathogens were isolated. Acidfast and alcohol-fast bacilli were not identified on direct smears. The Heaf test was grade III positive. A chest $x$-ray film revealed no definite abnormality other than a slight increase in left basal markings.

Her dyspnoea was not relieved by subcutaneous adrenaline, oral ephedrine, or intravenous aminophylline. Hypersalivation, which was a marked feature, was uninfluenced by oral atropine. As she continued to cough up $100 \mathrm{ml}$. of mucopurulent sputum daily, benzylpenicillin 1 mega unit six-hourly and streptomycin sulphate 0.5 g. 12-hourly, both intramuscularly, were given empirically from 19 to 27 April. As there was little change in her clinical state or in the character and volume of her sputum, chloramphenicol 500 